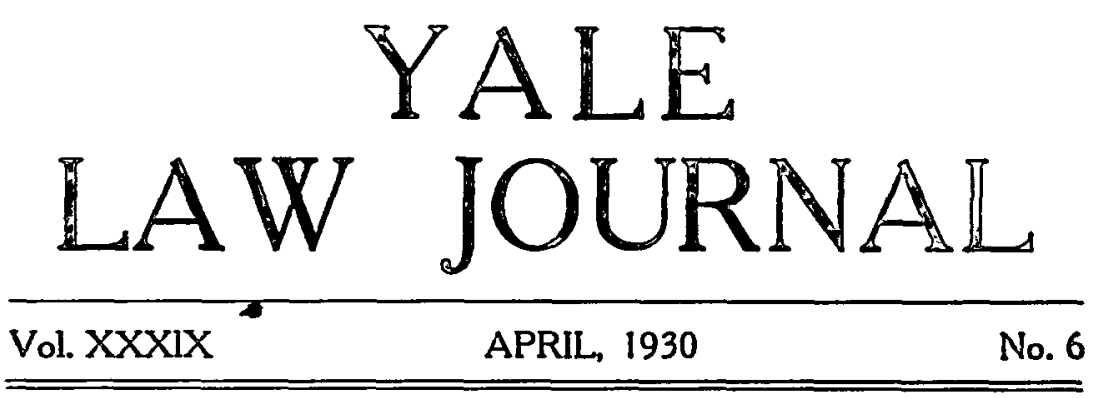

\title{
FUTURE INTERESTS IN CHATTELS PERSONAL
}

0

LEWIS M. SIMES

Any discussion of future interests in chattels personal may well begin with the admirable treatment of the subject by Professor John Chipman Gray in his treatise on the Rula Against Perpetuities. ${ }^{1}$ He first traced the history of the development of future interests in chattels real in English law, showing that a gift of a chattel real for life was once thought of as passing the absolute interest because of the technical doctrine that a life estate is greater than a term of years; that at an early period it was held to be possible to devise a term of years to $A$ for life and on his death to $B$, on the theory that $A$ had the whole estate subject to an executory devise in $B$; but that, so far as inter vivos transfers were concerned, the English law never recognized that there could be a valid gift over after a life estate in a term. He then showed that at first there could be no gift of a chattel other than an absolute one; he quotes from Brooke's Abridgement, "gift or devise of a chattel for an hour is forever." 2 We are told, however, that it was possible to give the use of a chattel by way of bailment, and that it came to be recognized that one could give the use of a chattel for life. A further step was reached when the courts held that if a chattel personal be bequeathed to $A$ for life, with remainder to $B, A$ would be regarded as having a life use with the general property in $B$. This last Professor Gray regarded as the better theory, pointing out, as does also Professor Holdsworth, ${ }^{3}$ that it is one of three possible theories as to the nature of a gift over after a life interest in a chattel personal.

1 Gray, Rule AGainst Perpetuitirs (3d ed. 1915) §§ 71-97, 789-850.

2 BROOKE, ABR (1576) Done et Remainder, pl. 57, Devise, pl. 13. The latter is quoted in GrAY, op. cit. supra note 1 , at 66 and 598.

37 HoldSWORTH, History of ENGLish LAW (3d ed. 1926) 475, 476. 
These three theories are as follows: (1) if a chattel personal is bequeathed to $A$ for life and on his death to $B, A$ may be thought of as having a legal use or possession, and $B$ as having a legal interest in the nature of a vested remainder; (2) $A$ may be regarded as having an absolute legal interest subject to an executory limitation in $B$, valid at law; (3) $A$ may have the whole legal interest in trust for himself for life and then in trust for $B$. Professor Gray discards the third theory as historically unsound and as unsupported by the cases. He devotes considerable space to a consideration of the merits of the first two theories, the second of which he concedes is approved by most of the English text writers. He explains this by suggesting that it is due to an unwarranted application of the theory of future interests in chattels real to chattels personal. Because a life estate is regarded as greater than any term of years is no reason why a man will live "longer than a picture or table will last." He supports the first view, not only by the historical argument already outlined, but by contending that in the two cases where it would make a difference in result the authorities are in accord with the first rather than the second theory."

\footnotetext{
4 Professor Gray summarizes these two points thus: "Suppose a chattel personal is bequeathed to an unborn person for life, and on his death to $A$. and his executors. If the gift to $A$. is vested (according to the old theory), then it is not too remote; if the gift to A. is executory, then it is void for remoteness. All the authorities, American and English, hold that the gift to $A$. is not too remote.

"Suppose a chattel personal is given to A. for life, with no limitation over. Then, on the old theory, upon A's death there is a reversion to the donor or his executors. On the modern English theory A. takes the whole property in the chattel, and there being no limitation over, it should. go on A's death to his executors. There is no English authority directly on the point. The weight of American authority is in favor of the reversion." GRAY, op. cit. supra note 1, at 610-611.

As to the first point, as is subsequently pointed out, we should not infer from this holding that the future interest after a life interest in a chattel personal is like a remainder in land in other respects merely because it resembles it in the applicability of the rule against perpetuities. Indeed, Professor Gray seems to recognize this to some extent when he refers to the interest as a quasi-remainder.

As to Professor Gray's argument about a gift of a chattel personal to. $A$ for life, with no gift over, his inference may be open to question. Evon if a life estate in a chattel were considered as a gift of the chattel, there might still be some sort of a reversionary interest in the donor, if we follow the analogy of the land law. If $A$, owning in fee simple absolute, conveys Blackacre to $B$ and his heirs, so long as a certain oak treo stands, it is the general view today that $B$ gets a determinable fee, and $A$ still has a possibility of reverter. Powell, Determinable Fees (1923) 23 CoL. L. REv. 207. Yet the feudal notion was that $A$ had conveyed a typo. of estate as great in quantum as he had. Just so, though a life interest. in a chattel is regarded as of the same type in quantum as a gift to $A$, his executors, administrators, and assigns, yet it may be treated like a de-
} 
From an historical standpoint, Professor Gray's treatment is scarcely open to criticism. But history alone cannot solve the problems now confronting the courts with respect to future interests in chattels personal. The gaps in the historical picture are too many; the cases in point are too few; the social interests contending for supremacy when they were decided were too insignificant to justify us in going far toward piecing out the law of future interests in chattels personal from historical materials. As Professor Holdsworth tells us: "The paucity of authority, and the obscurity of the rules, upon this question of the creation of successive interests in chattels personal, show that the whole topic is and has been a little explored backwater of the law." s

The principal critical observation which may be made concerning Professor Gray's discussion ${ }^{\circ}$, aside from his emphasis of historical materials, would appear to the writer to be this: There is too much tendency to assume that future interests in chattels can be discussed in terms of feudal concepts, that they are either executory limitations or remainders or reversions with most of the legal implications of those terms when applied to land. Would it not be more useful to consider the rights, privileges, powers, and other legal relations incident to these situations, rather than to apply in toto a concept from another field of law which resembles in one or two particulars a future interest in personalty? Merely because a present or future interest in personalty is like a life estate or remainder in land as to duration of the privilege of enjoyment or as to its validity

terminable interest, a sort of "fee simple" in the chattel with a special limitation. Thus, if we follow the terminology of the land law, the grantor would have a possibility of reverter, not a reversion. Of course Professor Gray would not have made that explanation because he took the position that there could be no such thing as a determinable fee or a possibility of reverter in land. And so he explains the English case of Eyres v. Faulkland, 1 Salk. 231 (1697), a decision recognizing a reversionary interest after life interests in a chattel real, as an authority for the proposition that a gift over after a life estate in a chattel is not like an execu. tory limitation. GRAY, op. cit. supra note 1 , at 597 .

The court's meaning in this case is so plain as to make it worth while to quote from the report. It reads: "As to the principal case, they held that all the remainders were good; ... for there may be possibility of reverter, even where no remainder can be limited, as the case of a gift to $A$ and his heirs while such a tree stands: no remainder can be limited over, and yet clearly the donor has a possibility of reverter, though no actual reversion; $a$ fortiori, there shall be a possibility of reverter, where a remainder may be limited over; for the testator gave but a limited estate, and what he has not given away must remain in him; and the words for life can be no more rejected in the last limitation than in the first." Eyres v. Faulkland, supra at 231.

57 HoLDSWORTH, op. cit. supra note 3, at 477 .

${ }^{6}$ Supra note 4. 
under the rule against perpetuities may not prove that the other legal consequences which attach to life estates and remainders in land are present. ${ }^{T}$

It is the purpose of this paper to inquire to what extent the rules of the law of estates and future interests in land are useful in solving questions relative to future interests in chattels personal. Incidentally some conclusions may be suggested as to the most desirable approach to problems concerning future interests in personalty. The question is considered from the standpoint of the various legal relations involved. Any discussion of the subject of consumable chattels is omitted from this paper. While brief reference is made to the questions of the acceleration of future interests in chattels, and the distinction between vested and contingent interests in chattels, a complete treatment of these subjects is beyond the scope of this discussion.

Before proceeding with a comparative analysis of the legal relations involved in future interests in land and personalty, it is desirable to make six observations which should be kept in mind in the succeeding discussion.

(1) Land law is concerned with a subject matter which differs materially from the subject matter of the law of chattels. Land is readily identifiable, fixed, immovable, indestructible; but chattels may be lost, disguised, consumed, or carried away. These differences are bound to be reflected to some degree in the law. Moreover, the objects included within the term chattels personal vary greatly from each other. Within that category we sometimes include stocks, bonds, and other intangibles, as well as heirlooms, money, and consumables.

(2) In spite of these inherent differences between land and chattels, one can discern a tendency in modern law to bring the law of chattels and of land more nearly together. This is doubtless due as much to changes in the land law as in the law of chattels. Feudal rules are being lopped off from the land law; statutes of descent and distribution tend more and more to distribute personalty and realty to the same persons. In England they are also distributed substantially in the same way. ${ }^{8}$ Indeed one of the objects of the English Law of Property Act of 1925 was to assimilate the law of land and chattels in so

\footnotetext{
${ }^{7}$ It is not contended that Professor Gray ignored specific legal consequences. Two of these are made the basis of his argument, referred to supra note 4. There is, however, a tendency to assume that some type of future interest recognized in the land law should be the basis of the rules as to chattels.

8 That is, both go to the personal representative on the owner's decease. See Land Transfer Act, 60 \& 61 VICT. c. 65, $\$ 1$ (1897); and Administration of Estates Act, 15 GEo. V, c. 23, \& 1 (1) (1925).
} 
far as possible. ${ }^{9}$ Whereas in feudal times holdings of personalty were comparatively insignificant, ${ }^{10}$ at the present time they frequently make up, at least if we include intangibles, a large part of a decedent's estate, and represent enormous wealth. Moreover, it is not uncommon in modern wills for land and personalty to be lumped together in one mass frequently by a residuary clause and to be distributed by a single set of dispositive provisions covering both kinds of property. Naturally, if such testamentary provisions are to be dealt with often, identities in the law of land and of chattels would simplify matters.

(3) We should not be misled by numerous dicta and arguments of American courts of last resort in which the applicability of the English law of estates and future interests in chattels is assumed. A few illustrations will suffice to explain what is meant by this observation. In the well-known case of Smith v. Bell," Mr. Chief Justice Marshall observed that "The rule that a remainder may be limited, after a life estate in personal property, is as well settled as any other principle in our law." What the case really holds is that where negro slaves were bequeathed for life, with a gift over to another after the death of the first taker, an assignee of the donee of the gift over could recover in trover against the husband of the one having the life interest after the latter's decease. That the future interest in question resembled a remainder in land as to the privilege of enjoyment would appear to be the extent of the actual decision on this point.

In Pollack v. Meyer Bros. Drug Co. ${ }^{12}$ the question at issue was whether or not certain future interests in personalty should have been scheduled by the holder thereof in a petition in voluntary bankruptcy in order to secure his dicharge. The court regarded the case as turning in part at least on whether or not the interest in question was "vested" or "contingent." In the opinion of Smith, Circuit Judge, he says: "Some confusion exists from the attempt to apply legal terms having their primary application to real estate to personal property." He then quotes Smith on Personal Property to the effect that, "Contrary to the ancient common law doctrine, it is now well established that there may be an interest in expectancy in personal property." He also quotes from a case which cited Fearne's well known definition of a contingent remainder in land. Judge Trieber, in his concurring opinion, quotes Fearne on Contingent Remainder's at some length, applying statements

9 UNDERHIL, The NeTr Conveyancing (1925) 7.

10 See Wirfinans, Real Property (21st ed. 1910) 10.

116 Pet. 68 (U. S. 1832).

t2 233 Fed. 861 (C. C. A. 8th, 1916). 
made by that author with respect to the distinction between vested and contingent remainders in land to future interests in personalty. The only thing decided in the case, however, is that the future interests in question should have been scheduled.

In Boal v. Metropolitan Museum of Art ${ }^{13}$ the court said: "At common law an interest in personal property by way of remainder may be limited after a life estate in such property." The court then laid down the proposition that contingent remainders with a double aspect could be created, and cited in support a passage from Fearne dealing exclusively with land, and the leading English case of Loddington $v$. Kime ${ }^{14}$ which recognizes contingent remainders in the alternative in land. The opinion does not refer to the fact that these authorities deal with interests in land, apparently assuming that the same rule applies to both types of property. The point about which these statements were made, however, was merely whether or not as a matter of construction a certain provision in a bequest of chattels was to be treated as a condition precedent rather than as a condition subsequent.

In Innes $v$. Potter ${ }^{15}$ the court said:

"The doctrine that personal property may be limited by way of remainder after a life interest created at the same time was early recognized in the United States [citing authorities]. The disposition of the later cases has been to dispense with all fictitious distinctions between the transfers of real and personal property, and to apply the same rules to both, except where distinctions are founded upon some substantial principle of law or are required by some statutory enactment."

Other statements of similar import may be found in some of the cases involving future interests in slaves to which further reference will be subsequently made.

(4) There are certain recognized historical differences between the law of realty and the law of personalty which are still important in our legal system. The Statute of Uses was inapplicable to chattels. The same is true of the Statute De Donis, so that fee tail estates in chattels were obviously impossible. On the decease of the owner, land passed to the heir or devisee, while chattels passed to the administrator or executor. A sharp distinction exists between freehold and non-freehold interests in land, although the same distinction was never drawn as to interests in chattels. While it is not of much significance

\footnotetext{
13298 Fed. 894 (C. C. A. 2d, 1924).

141 Salk. 224 (1695).

15130 Minn. 320, 153 N. W. 604 (1915).
} 
today, it may also be added that the notion of feudal tenure was not applied to chattels personal..$^{20}$

(5) American cases involving future interests in slaves should not be given the same force and effect as precedents as is accorded to adjudications relative to interests in other kinds of chattels.

A brief consideration of the slave cases as a group may be pertinent to this discussion. Slaves were said to be personalty, but the early decisions disclose that they were much more closely connected with interests in land than most other chattels. ${ }^{17}$ By statute in Virginia and Kentucky it was possible to annex slaves to land and give them in tail. ${ }^{\text {is }}$ In Louisiana a statutory provision declared slaves to be immovables. ${ }^{10}$ In a Virginia case $=$ decided in colonial days we find the question presented to the court whether slaves could be entailed without being annexed to land. Counsel is reported to have made the significant observation that "The legislature, considering the intimacy of connection between slaves and lands, and that the latter in this country could be of but little profit without the former, thought it expedient to declare them real estate." The majority of the court were of opinion that slaves unattached to land could not be entailed, but the case indicates that attempts to create such an estate were common. Indeed, one case in Jefferson's Virginia reports would seem to indicate that the court thought slaves were subject to the Statute of Uses.21

Nevertheless, the courts fully recognized that slaves were essentially chattels. In Kentucky, in spite of an act which declared slaves to be real estate, the court held that the law of the domicile of the owner, and not of the situs of the property, applied where slaves in Kentucky were owned by a person in

${ }^{16}$ It should be observed, however, that the notion of tenure and the notion of estates are not identical. See 2 HoLDsworTu, op. cit. supra noto 3 , at 349-352. Hence, while we may discard any rule incident to feudal tenure when dealing with chattels, we do not necessarily discard the doctrine of estates on that account.

${ }_{17}$ See, for example, the observation of the court in Beadle v. Hunter, 3 Strob. 331, 336 (S. C. 1848), where, after indicating that the rule as to tacking successive adverse possessions should be the same in the case of slaves and of land, the court said: "Indeed every day's experience eatisfies me, that land and slaves should be placed upon the same footing, in every respect."

18 Cf. Blackwell v. Wilkinson, Jeff. 73 (Va. 1768); Dade v. Alexander, 1 Wash. 30 (Va. 1791); McNair v. Hawkins, 4 Bibb. 390 (Ky. 1816).

$19 \mathrm{Gf}$. McCollum v. Smith, Mieigs 342 (Tenn. 1838). Of course, the Louisiana law, due to civil law influence, may well have reached difierent conclusions than other states on these matters, anyway.

${ }^{20}$ Blackwell v. Wilkinson, supra note 18.

21 Custis v. Fitzhugh, Jeff. 72 (Va. 1768). 
Indiana. ${ }^{22}$ "Considering them merely as property in the abstract," said the court in that case, "are they personal or real estate? They must surely be admitted to be personal. They are persons, and are, therefore, in their nature personal. They are movable and perishable, and therefore are not real in their nature. The law which imparts to them, for a special purpose and to a qualified extent, the factitious quality of realty, still considers them, for most purposes, and to a greater extent, personalty." Actions of detinue, trover and replevin might be brought against a converter of a slave, ${ }^{28}$ and, in the absence of a statute otherwise providing, they passed to the executor or administrator, and not to the heir, on the death of the owner. ${ }^{24}$

That attempts to create future interests in slaves were common is indicated, not only by the fact that the bulk of the American cases involving future interests in chattels prior to the Civil War were slave cases, but also by legislation in some states requiring bills of sale of slaves, or instruments creating future interests in slaves, to be registered. ${ }^{25}$

In conclusion, with reference to the significance of slave cases as authorities, we may summarize as follows: (a) unlike most chattels today, there was a common desire that slaves go by devise or descent with the land of the owner; (b) slaves were nevertheless a frequent subject of sale apart from land; (c)

22 See Sneed v. Ewing, 5 J.J. Marsh. 460, 482 (Ky. 1831).

${ }^{23}$ Cases in which these actions are brought are numerous. Detinue for slaves: Chinn v. Respass, 1 T. B. Mon. 25 (Ky. 1824) ; M'Donald, Adm'r v. Walton, 2 Mo. 48 (1828); Clarkson v. Booth, 17 Gratt. 490 (Va. 1867); Price v. Talley's Adm'r, 18 Ala. 21 (1850). Trover: Easloy's Ex'rs v. Easley, 18 B. Mon. 86 (Ky. 1857); Smith v. Bell, supra note 11; Booth v. Terrell, 16 Ga. 20 (1854). Replevin: May v. Rockett, 25 Miss. 233 (1852). 24 May v. Rockett; and cf. Easley's Ex'rs v. Easley, both supra noto 23.

In Chinn v. Respass, supra note 23, the court had before it the question of whether or not a will bequeathing a testator's "personal estate" should be construed to include slaves. The court held that slaves should be included, observing: "Slaves were, indeed, as we have already observed, declared by law, to be real estate, and directed, to descend as lands doscended, to the heir at law. But, it does not follow that the testator, by the devise of the personal estate, did not intend that his slaves should pass; for although slaves were, by law, made real estate, for the purposes of descent and dower, and perhaps some others, yet they had in law many of the attributes of personal estate. They would pass by a nuncupative will, and lands would not; they were liable to be sold for the payment of debts, and lands were not; they could be limited in a grant or devise, no otherwise than personal chattels, and personal actions might bo brought to recover the possession of them. Besides, they were, in their naturo, personal estate, being movable property, and such as might attend tho porson of the proprietor wherever he went, and in practice they were so considered and treated by the people in general." Ibid. 28.

${ }^{25}$ Cases in which such statutes are referred to are: Palmer v. Popelston, 8 N. C. 307 (1821); Lightfoot v. Strother, 9 Leigh 451 (Va. 1838); Bank v. Holland, 99 Va. 495,39 S. E. 126 (1901). 
since attempts to create future interests in slaves were also frequent, we find registration legislation designed to make slaves more readily alienable and to avoid the uncertainty of title which might result from the existence of future interests; (d) nevertheless, for many purposes the common law of chattels personal was applied to legal interests in slaves.

We may conclude that, while precedents involving future interests in slaves are not without force in some situations, these cases must be treated in a class by themselves; and because a rule has been applied to future interests in slaves, it does not necessarily follow that the same rule should be applied to future interests in chattels personal today.

(6) The modern tendency in the creation of future interests in chattels personal is to create a trust for the benefit of the person who is to enjoy the chattel in the future. Indeed, it may almost be said to be a slip in draughtsmanship to create future interests in chattels personal without the intervention of a trust. In view of the fact, therefore, that the slave cases cannot be given very great weight for most purposes, though they constitute a large part of the early cases, and that the modern cases quite generally involve a trust, we are left with few controlling precedents with respect to future interests in chattels personal cognizable by courts of law. As will appear later, in some situations the same rules are applicable whether the future interest be created through the intervention of a trust or not. In this connection, it should be stated that, unless othervise indicated, the situations herein discussed are those where future interests in chattels are sought to be created without the intervention of a trust.

With these observations in mind, we may now proceed to consider the applicability of the law of estates and future interests in land to future interests in chattels personal. At the outset we may ask: what do we mean by estates in land? The usual definition of an estate, as "such interest as the tenant has" in lands, tenements and hereditaments, ${ }^{20}$ does not aid us particularly in this connection. Nor do we go farther by recalling that estate is from the Latin word status and signified the condition or circumstances of the feudal tenant with respect to the land. This much is obvious: a property system is conceivable in which there are no fixed types of interests or rigid categories such as life estates and fees simple-in which one may provide for practically any combination of legal consequences

26 "An estate in lands, tenements, and hereditaments, signifies such interest as the tenant has therein; so that if a man grants all $h$ is cstate in Dale to $A$. and his heirs, everything that he can possibly grant shall pass thereby." 2 BL. Comm. "103. 
by so indicating in the creating instrument, somewhat as he might set out the stipulations in a contract. But our land law is not such a system. There are more or less rigid categories called estates, differentiated from one another primarily by provisions concerning the extent of enjoyment. If these provisions as to extent are expressed in the creating instrument, other fixed and definite legal consequences follow as to each type of estate, such as devolution on intestacy of the owner, liability for waste, destructibility or indestructibility, as the case may be, whether the creator of the interest intended such consequences or not.

The historical picture of the law of estates must not be overlooked. No one has better expressed it than the authors of Pollock and Maitland's History of English Law, when they say:

"Proprietary rights in land are, we may say, projected upon the plane of time. The category of quantity, of duration, is applied to them. The life-tenant's rights are a finite quantity; the fee-tenant's rights are an infinite, or potentially infinite, quantity; we see a difference in respect of duration, and this is the one fundamental difference. . . The estate for life is smaller than the estate in fee; it is infinitely smaller; so that if the tenant in fee breaks off and gives away a life estate, or twenty life estates, he still has a fee." ${ }^{27}$

As Blackstone put it, these lesser estates-fees tail and life estates-were "carved" out of the fee simple. There could be any number of life estates, any number of fee tail estates, but only one fee simple. Other writers have thought that the outstanding feature of this historical picture of estates was that the common law future estate, the reversion or the remainder, took effect by way of "succession" rather than by "substitution"; that vested future interests were thought of as having a present existence subject only to the termination of preceding estates in possession, rather than as coming into existence when they took effect in possession. ${ }^{28}$ While this picture is invaluable in explaining the past, it is hardly adequate to interpret the present or to predict the future.

Viewed analytically, the law of estates involves at least three things: (1) There are certain fixed types differentiated from each other primarily by the duration of the privilege of enjoyment; they are the fee simple, the fee tail, the life estate, the term of years, and the tenancy at will. (2) If one indicates an intention with respect to the duration of the enjoyment of the

272 Pollock and Maitland, History of ENGLish LaW (2d ed. 1899) 10.

28 See Jenks, Future Interests in Land (1904) 20 L. Q. REv. 280; MARKBY, ELEMENTS OF LAW (6th ed. 1905) § 330; GraY, op. cit. supra note 1 , at 79, n. 3 . 
land, the law implies a more or less fixed group of legal consequences, whether intended by the creator of the interest or not. (3) There are certain general rules applicable to these types of estates as related to one another, such as rules about acceleration and merger.

Estates may be either present or future. It is possible to create a future privilege of enjoyment of land either in fee simple, in fee tail, for life or for years.

Future estates and interests are also divided into more or less fixed classes on the basis of the manner of creation of the interest or the manner in which the interest is to take effect in possession. These classes are ordinarily stated as follows: the reversion, the remainder, the executory limitation, the possibility of reverter, and the right of entry for condition broken. If sufficient is indicated in the creating instrument to lead us to conclude that one of these future interests has been created, a more or less fixed group of legal consequences will follow, whether intended by the creator of the interest or not. Likewise there are general rules applicable to these interests as related to each other or to interests in possession.

We are now prepared to inquire: what present privileges of enjoyment may be created with respect to chattels personal? Obviously, there may be an absolute transfer of the chattel. The transferee, however, could not be said to have a fee simple, since on his death the chattel would pass to his executor or administrator.

No privilege of enjoyment corresponding to the fee tail estate in land can be created in chattels. The statute De Donis is inapplicable to chattels of any kind, and a gift of chattels to one and the heirs of his body, or with words of the same import, would give the donee an absolute interest. ${ }^{29}$ The law simply

29 To the effect that there can be no estate tail in personalty, and that an attempt to create such an interest creates an absolute interest, are the following: Young v. Kinnebrew, 36 Ala. 97 (1860); Smith v. Greer, 88 Ala. 414, 6 So. 911 (1889); Denson v. Thompson, 19 Ark: 66 (1857); Mroody v. Walker, 3 Ark. 147 (1840); Maulding v. Scott, 13 Ark. 88 (1852); Hudson v. Wadsworth, 8 Conn. 348 (1831); Watts v. Clardy, 2 Fla. 369 (1848); Gray v. Gray, 20 Ga. 804 (1856) (statutory provision); Albee v. Carpenter, 12 Cush. 382 (Miass. 1853) ; Chism's Adm'r v. Williams, 29 Mo. 288 (1860); Floyd v. Thompson, 20 N. C. 616 (1839); Nichols v. Cartwright, 6 N. C. 137 (1812); King v. Beck, 12 Ohio 390 (1843); Potts' Appeal, $30 \mathrm{~Pa} .168$ (1858); Smith's Appeal, $23 \mathrm{~Pa} 9$ (1854); Cooke v. Bucklin, 18 R. I. 666, 29 Atl. 840 (1894); Account of Tillinghast, 25 R. I. 338, 55 ;Atl. 879 (1903); Dott v. Cunningham, 1 Bay 453 (S. C. 1791); Stockton v. Martin, 2 Bay 471 (S. C. 1802); Mroore v. Broolis, 12 Gratt. 135 (Va. 1855); Williamson v. Daniel, 12 Wheat. 568 (U. S. 1827); cf. Goldsby v. Goldsby, 38 Ala. 404 (1862); Powell v. Glenn, 21 Ala. 458 (1852); Webbe v. Webbe, 234 Ill. 442, 84 N. E. 1054 (1908), 17 L. R. A. (N.S.) '1079 (1909); Norris v. Beyea, 13 N. Y. 273 (1855); Eichelberger 
construes the language as an attempt, effectual though inapt, to pass the absolute interest. It is not correct to say, however, that every limitation which would create a fee tail in land produces an absolute interest in personalty. In the case of a gift over on failure of issue, the same language which is construed to mean an indefinite failure of issue in the case of land may be held to mean a definite failure of issue in the case of personalty..$^{80}$ Thus the limitation when applied to land would give an estate tail, but when applied to personalty the first limitation in some cases might be construed as a gift for life, with a gift over on a contingency.

The present privilege of enjoyment of chattels for life may be created. ${ }^{31}$ In North Carolina the courts have held that this may be done only by will, a gift inter vivos being construed in that jurisdiction as a gift of the absolute interest. ${ }^{32}$

It needs no citation of authority to show that possession of a chattel may be granted for a specific term or at will. Such transactions are commonly called bailments. ${ }^{28}$

v. Barnetz, 17 S. \& R. 293 (Pa. 1828) ; Doty v. Chaplin, 54 Vt. 361 (1882).

One occasionally comes across statements in the opinions to the effect that the law recognizes estates tail in chattels, but all such remarks would seem to be incorrect. Cases of this sort are: Horton v. Upham, 72 Conn. 30, 43 Atl. 492 (1899) ; St. John v. Dann, 66 Conn. 401, 410, 34 Atl. 110, 116 (1895) ; Talbot v. Snodgrass, 124 Iowa 681, 100 N. W. 500 (1904).

Attention should be called to the fact that at the present time an equitable fee tail estate in a chattel is permitted by the English law. Seo Law of Property Act, 15 Geo. V, § 130 (1) (1925). In Cheshire, ModERN REAL Property (2d ed. 1927) 359, the enactment is explained, in part, as follows: "Before the Act it sometimes happened that when freeholds were limited by settlement to a series of legal tenants for life and in tail, it was desired to give the persons who for the time being were entitled to the land the enjoyment of certain family heirlooms such as valuable pictures and the like. As the heirlooms, being chattels, could not be carved into estates in the same way as the land, the only mode of carrying out the intention was to vest them in trustees upon trust that they should go along with the land so far as the rules of law and equity would permit. In such a case law and equity permitted any legal life tenant of the land for the time being to have an equitable life interest in the heirlooms, but required that the absolute ownership should vest in the first person to get an estate tail in the land."

For a discussion of decisions prior to the Law of Property Act with reference to settlements of heirlooms to go with land "as far as law and equity will permit," see GraY, op. cit. supra note 1, §§ 363-367; and of. Portman v. Portman, [1922] 2 A. C. 473, discussed by Professor Vance in Comment (1922) 32 Yaue L. J. 56-59.

${ }^{30} \mathrm{Cf}$. for example, Forth $\nabla$. Chapman, 1 P. Wms. $663 \cdot(1720)$.

s1 Decisions on this point are very numerous. See the cases infra notes 34 and 36.

32 Outlaw v. Taylor, 168 N. C. 511, 84 S. E. 811 (1915) ; Dail v. Jones, 85 N. C. 221 (1881) ; Morrow v. Williams, 14 N. C. 263 (1831); Graham v. Graham, 9 N. C. 322 (1823).

${ }^{33} \mathrm{Cf}$. May v. O'Neal, 125 Ala. 620, 28 So. 12 (1900), for an example of 
It should be further noted that there are other present interests in chattels which do not come within any of the types mentioned. Among these are the interests of lienors, pledgees, and conditional vendors.

Without carrying the comparison of present interests so far as to include a discussion of special limitations and conditions subsequent, since those matters will be referred to later, let us now inquire to what extent future interests in chattels may be created having the same period of enjoyment as future interests in land. The situation in the American law may be summarized as follows: except in Delaware and possibly Pennsylvania, privileges of enjoyment of chattels analogous to reversions after life estates are permitted. ${ }^{34}$ Presumably, such a reversionary interest would exist in the creator of a bailment for a term or

a bailment for a specified term. And cf. Bailey v. Colby, 34 N. H. 29 (1856), where the court distinguishes between the legal consequences of a bailment at will and a bailment for a term.

The question may be raised, are not life interests in chattels merely bailments of a sort? In Booth v. Terrell, $16 \mathrm{Ga} .20$ (1854), the court sought to distinguish between the formalities necessary for the creation of a bailment for life in a chattel and a life interest. But the distinction seems without foundation; and in the following cases a "loan for life" was apparently regarded as indistinguishable from a gift of a chattel for life: Watts v. Clardy, 2 Fla. 369 (1848); Nicols v. Cartwright, 6 N. C. 137 (1812). But the courts are inclined to treat a bailor's interest as a present interest and otherwise to regard it in a somewhat different light from that of a grantor of a life interest in a chattel.

${ }^{34}$ To the effect that a reversionary interest after a gift of a chattel for life is valid, are the following: Evans' Appeal, 51 Conn. 435 (1883); Haralson v. Redd, 15 Ga. 148 (1854); Boyd v. Strahan, 36 Ill. 355 (1865); McCall v. Lee, 120 III. 261, 11 N. E. 522 (1887); Johnson's Adm'r v. Johnson, $104 \mathrm{Ky} .714,47 \mathrm{~S}$. W. 883 (1898); Nickerson v. Bovly, 8 IJetc. 424 (ITass. 1844); Brown v. Kelsey, 2 Cush. 243 (Mass. 1848); Boston Safe Deposit \& Trust Co. v. Buffum, 186 Mass. 242, 71 N. E. 549 (1904); State v. Probate Court, 102 Minn. 268, 113 N. W. 888 (1907); Vannerson v. Culbertson, $10 \mathrm{Sm}$. \& MT. 150 (Miss. 1848); Harris v. McLaran, 30 Miss. 533 (1855) ; French v. Hatch, 28 N. H. 331 (1854); Deats v. Ziegener, 82 N. J. Eq. 605,89 Atl. 31 (1913); Anonymous, 3 N. C. 161 (1802); James' Ex'rs v. Miasters, 7 N. C. 110 (1819); Black v. Ray, 18 N. C. 331 (1835) ; Creswell v. Emberson, 41 N. C. 151 (1849); IIcKinley v. Scoth, 49 N. C. 197 (1856); Geiger v. Brown, 4 IICC. 427 (S. C. 1828); MIorris v. Owen, 2 Call. 520 (Va. 1801); Bartlett v. Patton, 33 W. Va. 71, 10 S. E. 21, 5 L. R. A. 523 (1889). Contra: State v. Savin, 4 Har. 5G, n. (Del. 1843); Derickson v. Garden, 5 Del. Ch. 323 (1880); Williams v. Floyd, 12 Del. Ch. 256, 112 Atl. 377 (1920); Grant v. Mullen, 15 Del. Ch. 174, 138 Atl. 613 (1926). Cf. also Appeal of Merkel, $109 \mathrm{~Pa} .235$ (1885) ; Drennan's Appeal, $118 \mathrm{~Pa} .176,12$ Atl. 348 (1888); Kanę's Es. tate, $185 \mathrm{~Pa}$. 544, 40 Atl. 90 (1898); In re Rogers' Estate, $245 \mathrm{~Pa} .206$, 91 Atl. 351 (1914); Freeman's Estate, 220 Pa. 343, 69 Atl. 816 (1908); Bank v. Hartman, $8 \mathrm{~Pa}$. Super. 170 (1898); Hartman's Estate, $11 \mathrm{~Pa}$. Super. 35 (1899) ; Simpson's Estate, 34 Pa. Super. 115 (1907) ; Yeity's Estate, $90 \mathrm{~Pa}$. Super. 130 (1926). 
at will, though the courts would probably regard it as a present interest. ${ }^{35}$ An interest analogous to a remainder after a life estate may also be created. ${ }^{36}$ Such a remainder interest may either be limited to take effect at all events on the termination of the life interest, or it may be limited to take effect on some condition precedent in addition to the termination of the life interest. That is, it may be like a vested remainder or like a contingent remainder as to the privilege of enjoyment. Could a "vested" or "contingent remainder interest" be created in a chattel to take effect after an interest for a term or at will? There seems to be little authority on the point, but no reason is perceived why it could not be done. ${ }^{37}$ A gift over of a chattel after a present gift to one and his executors, administrators,

35 See supra note 33.

36 To the effect that an interest in the nature of a remainder, after a gift of a chattel for life, may be created, are the following: Underwood v. Underwood, 162 Ala. 553, 50 So. 305 (1909); King v. Stevens, 146 Ark. 443, 225 S. W. 656 (1920) ; Bishop v. Groton Sav. Bank, 96 Conn. 325, 114 Atl. 88 (1921); Longworthy v. Chadwick, 13 Conn. 42 (1838); Griggs v. Dodge, 2 Day 28 (Conn. 1805); Taber v. Packwood, 2 Day 52 (Conn. 1805) ; State v. Warrington's Ex'r, 4 Har. 55 (Del. 1843); Williams v. Floyd, supra note 34; Horn's Ex'rs v. Gartman, 1 Fla. 63 (1846) ; Crawford v. Clark, 110 Ga. 729, 36 S. E. 404 (1900); Phillips v. Crews, 65 Ga. 274 (1880); Hetfield v. Fowler, 60 Ill. 45 (1871); Trogdon, Adm'r v. Murphy, 85 Ill. 119 (1877); Pratt v. Skiff, 289 Ill. 268, 124 N. E. 534 (1919); Gahan v. Golden, 330 Ill. 624, 162 N. E. 164 (1928); Dickinson v. Griggsville National Bank, 209 Ill. 350, 70 N. E. 593 (1904); Chaso v. Howie, 64 Kan. 320,67 Pac. 822 (1902) ; Hornsby v. Hornsby, $185 \mathrm{Ky}$. 847, 216 S. W. 88 (1919); Stallcup v. Cronley's Trustee, $117 \mathrm{Ky} .547,78$ S. W. 441 (1904); Grayson v. Tyler's Adm'x, $80 \mathrm{Ky.} 358$ (1882); Knight v. Donahoo's Heirs, 3 B. Mon. 277 (Ky. 1842); Keen \& West v. Macoy, 3 Bibb. 39 (Ky. 1813) ; Sampson v. Randall, 72 Me. 109 (1881); Sellick v. Sellick, 207 Mich. 194, 173 N. W. 609 (1919), 5 A. L. R. 1621 (1920); Stuart v. Swanzy, 12 Sm. \& M. 684 (Miss. 1849); Hitchcock v. Glendennin, 6 Mo. App. 99 (1878); Abbott v. Wagner, 108 Neb. 359, 188 N. W. 113 (1922); In re Van Wagoner's Estate, 97 Atl. 893 (N. J. Preog. 1916); Westcott v. Cady, 5 Johns. Ch. 334 (N. Y. 1821); Matter of Brandreth's Estate, 169 N. Y. 437, 62 N. E. 563 (1902) ; Smith v. Van Ostrand, 64 N. Y. 278 (1876) ; Snedeker v. Congdon, 41 App. Div. 433, 58 N. Y. Supp. 885 (2d Dept. 1899) ; Bogle v. N. C. R. R., 51 N. C. 419 (1859); Min Young v. Min Young, 47 Ohio St. 501, 25 N. E. 168 (1890); Cook v. Collier, 62 S. W. 658 (Tenn. Ch. 1901) ; Bufford v. Holliman, 10 Tex. 560 (1853); Bradley v. Mosby, 3 Call 44 (Va. 1801); Clarkson v. Booth, 17 Gratt. 490 (Va. 1867); Morse v. Stoddard's Estate, 90 Vt. 479, 98 Atl. 991 (1916); Smith v. Boll, iupra note 11.

37 In Merrill v. Tevis, 2 Dana 162 ( $\mathrm{Ky} .1834$ ), the court assumed that a semainder after an interest in a chattel for a fixed term could be created, and discussed the future interest in question as if it were of that sort, but the facts indicate it was rather a reversionary interest after a bailment for a term. Jolly v. Wills, 2 Ch. R. 137, 21 Repr. 639 (1678-79) holds that such an interest is valid. Cf. Shafer v. Tereso, 133 Iowa 342,110 N. W. 846 (1907). 
and assigns is valid. ${ }^{3 s}$ Such a future interest is like an executory limitation as to the privilege of enjoyment. When the owner of a fee simple absolute in land conveys a determinable fee, he retains a possibility of reverter.59 Suppose chattels were given to $A$, his executors and administrators, so long as a certain oak tree stands. Would $A$ retain a future privilege of enjoyment like a possibility of reverter in land? In Matter of Termy, a case involving the application of the New York succession tax, a will bequeathed certain legacies to a charitable corporation, "to be retained by it so long and so long only as the said corporation shall continue to exist under its present name and maintain under that name a home for destitute aged men and women in the said village. ..." The will further provided that if the corporation should cease to exist under said name or cease to maintain a home as provided, the principal of the fund should go to testator's heirs at law. The court referred to the interest of the heirs as a possibility of reverter and evidently regarded it as valid; but all the court actually decided was that the heirs were under no duty to pay the tax while the property was properly held by the charitable corporation. Without doubt such a privilege of enjoyment could be created."1 Cases like O'Mahoney

38 Cases recognizing the validity of executory interests in chattels personal are numerous. To that effect are: Hudson v. Wadsworth, aupra note 29; Bradford v. Mackenzie, 131 MIA. 330, 101 Atl. 7T4 (1917); Homer v. Shelton, 2 IIetc. 194 (Mass. 1841); Norris v. Beyea, supra note 29; Moffat's Ex'rs v. Strong, 10 Johns. 12 (N. Y. 1813) ; Haughton v. Benbury, 55 N. C. 337 (1856) ; Briggs v. Hopkins, 103 Ohio St. 321,132 N. E. 843 (1921); Rapp v. Rapp. 6 Pa. 45 (1847); Hill v. Hill, Dud. Eq. 71 (S. C. 1836) ; Brummet v. Barber, 2 Hill 543 (S. C. 1834); Behrens v. Baumann, 66 W. Va. 56, 66 S. E. 5 (1909); Dunn v. Bray, 1 Call 338 (Va. 1798). And see cases cited in Gray, op. cit. supra note 1, at 607, n. 5 .

A number of Arkansas cases, following a dictum in Iloody v. Walker, 3 Ark. 147 (1840), have taken the position that an executory limitation cannot be created in a chattel. Slaughter v. Slaughter, 23 Ark. 356 (1861); Robinson v. Bishop, 23 Ark. 378 (1861); Scull v. Vaugine, 15 Arl. 695 (1855); Gaines v. Briggs, 9 Ark. 46 (1848). This conclusion may be traced to a dictum in Patterson v. Ellis, 11 Wend. 259 (N. Y. 1833), since repudiated in New York [Norris v. Beyea, supra note 29], and on a statement of Kent's [2 KENT CoMr. \$352] which was misconstrued, and indeed misquoted. Further doubt is thromn on the Arkansas decisions by the dictum of the court in Bunch v. Nicks, 50 Ark. 367, 376 (1867).

The validity of an executory limitation in a chattel has also been denied in Talbot v. Snodgrass, supra note 29.

${ }^{39}$ See Powell, op. cit. supra note 4; Vance, Rights of Revcrter and the Statute Quia Emptores (1927) 36 YALE L. J. 593.

40218 N. Y. $218,220,112$ N. E. 931,932 (1916). It may be noted that in New York a statute makes certain provisions with reference to the limitation of future interests in personalty. See infra note 110.

1 To that effect is also the case of Gamble v. Gates, 92 Arich. 510, 52 N. W. 941 (1892). In Boal v. Metropolitan Miseum, 292 Fed. 303, 30̃̃ (S. 
v. Burdett ${ }^{42}$ and Horn v. Foley, ${ }^{43}$ sustaining a reverter on the failure of a succeeding interest, would seem to be authorities for that proposition.

Could there be an interest in personalty analogous to a right of entry for condition broken? The very phrase seems to indicate a denial of the proposition, since one cannot "enter" chattels nor have a right to do so. The actual entry feature of the interest in land, however, has pretty much faded out of the picture in recent years. What the grantor of land with a condition subsequent has is a power to terminate the grantee's interest when the condition is broken, and an option or privilege to exercise the power. The real question is, can one grant a chattel on a condition subsequent in such a way that on the breach of the condition the grantee's interest will not terminate, but will only terminate on the grantor exercising an option to terminate it? In Green v. Old People's Home the Supreme Court of Illinois held that a legacy bequeathed to the Old People's Home was upon a condition subsequent and not a conditional limitation. The court indicated that the condition subsequent operated like the corresponding interest in land, so that the present estate was not divested until a forfeiture was declared. The court held valid the power of the testator's heir to declare a forfeiture, observing' that:

"The rule in this state is that the general principles applicable to the vesting of real estate apply, generally, to gifts of personal property [citing cases]; and the fact that the gifts in question are of personal property instead of real estate will therefore make no difference in our consideration of this question." 45

In Palmer v. President of Union Bank ${ }^{\text {so }}$ the same distinction

D. N. Y. 1923), rev'd, 298 Fed. 894, 903 (C. C. A. 2d, 1924), Judge Learmed Hand recognizes that an interest like $a$ base or determinable fee could be created in a chattel.

427 Eng. \& Ir. App. 388 (1874).

4313 App. D. C. 184 (1898).

44269 Ill. 134, 109 N. E. 701 (1915).

45 Ibid. 142,109 N. E. at 704.

4617 R. I. 627,24 Atl. 109 (1892). In that case the court said: "Provisions of this sort are of two kinds, - one, where upon failure of the trust there is a condition of reverter to the grantor or his heirs; and the other where there is a limitation over to others, in a manner which makes it possible for the time of taking to go beyond the alloted time of a life or lives in being and 21 years thereafter. The former case is not within the rule against perpetuities, because a present vested and transmissible interest is reserved; a right of entry upon condition broken. . . . The validity of such a provision, therefore, depends upon the question whether it is a condition or a conditional limitation." Ibid. 632, 24 Atl. at 110.

While the observations are open to serious criticism, it would seem, since the case concerned personalty, that the court thought there was something known as a right of entry in personalty. 
was made between a condition and a conditional limitation in chattels, though the remarks are mere dicta.

In addition to these future privileges of enjoyment similar to those involved in future interests in land, may also be mentioned the interest of the conditional vendee in a conditional sale, the interest of a pledgor, and the interest of a lienee. It is difficult if not impossible to force these interests into any of the categories we have considered. The extent and character of the future enjoyment depends ordinarily upon certain types of contracts. It is true that these interests are not ordinarily spoken of as future interests, but there is a future privilege of enjoyment which would seem to be somewhat like that involved in the usual types of future interests. It may also be suggested that likewise in the land law there are certain interests which do not fit into the categories, such as the interests of the mortgagor and mortgagee, the interest of the beneficiary of a resulting trust, a wife's inchoate dower interest, or, in early English law, the so-called tenancy by elegit. Hence the existence of these anomalous interests does not totally preclude us from following the analogy of the land law if it is otherwise desirable.

More difficulties arise, however, when we begin to consider the other legal consequences attached to these respective privileges of enjoyment which correspond to legal relations involved in future interests in land. According to the common law, the reversion and the vested remainder in land involved a power of alienation. Apparently the right of entry, the possibility of reverter, and also the contingent remainder and executory limitation were regarded as inalienable. But in some cases at least, the two types last mentioned may now, in many jurisdictions, be alienated. Is the same true of the analogous interests in personalty? Without doubt, "reversions" and certain forms of "remainders" and "executory limitations" in personalty have been held to be alienable." Whether interests like possibilities of reverter and rights of entry in personalty (if there be such interests) are alienable, the cases do not disclose. In Palmer $v$. President of Union Bank ${ }^{\text {is }}$ the court said such an interest was alienable, but this observation can hardly be relied upon.

If there is such a thing as a "right of entry" in personalty, we would naturally inquire, do the doctrines of waiver apply to it? And is it subject to the rule against perpetuities? As to

4: Smith v. Bell, supra note 11; Franklin v. Roberts, 36 N. C. 560 (1843); Ray v. West, 194 Ky. 96, 238 S. W. 167 (1922) ; Real Estate Co. v. Dearborn, 119 Me. 168, 109 Atl. 816 (1920); National Park Bank v. Billings, 144 App. Div. 536, 129 N. Y. Supp. 846 (1st Dep't 1911) ; Grayson v. Tyler's Adm'x, supra note 36.

\$8 Supra note 46. 
waiver, nothing can be said. In Green v. Old People's Home ${ }^{40}$ it is clear that the so-called "right of entry" was not regarded as subject to the rule against perpetuities, for otherwise it would have been held void. The dictum in Palmer $v$. President of Union Bank ${ }^{50}$ is likewise to the effect that the rule does not apply to such an interest. As a matter of fact it is difficult to see how the existence of such an interest can be justified. No doubt, there would be no legal objection to a donor of a chattel reserving to himself a power to revest title in himself. The doctrines as to powers of appointment would seem to be ample to cover such a situation; and no reason is perceived why such a power could not operate by way of executory limitation, unless there be some doctrine that there can be no executory limitation in a donor. But it would seem that such an interest should be subject to the rule against perpetuities.

In the land law we have an elaborate system of rules as to the extent of the privilege of enjoyment of the holder of the present interest and as to the right of the owner of the future interest to bring an action at law or in equity when he oversteps the bounds of those privileges. Such an overstepping of the privileges is ordinarily referred to as waste, and varies where the holder of the present interest has a tenancy at will, a term of years, a life estate, or an estate tail. It would appear that the cases disclose no such elaborate gradation of privileges in the case of chattels. The privileges of the holder of a chattel at will or for a term are pretty much determined by contract. But this is really a matter of the law of bailments and can hardly be discussed at length here. In the case of land, it seems that there are many situations where the holder of the future interest would have no right of action regardless of the sort of user to which the land was being subjected. Instances of this might arise in the case of a remainder after a fee tail or an executory limitation after a fee simple.51 Yet, so far as can be ascertained from the cases, the holder of a future interest in chattels would never be without a remedy. ${ }^{52}$ This conclusion seems reasonable when we consider that the present holder of a chattel can totally destroy it, but one cannot totally destroy the subject matter of

49 Supra note 44.

so Supra note 46.

51 Equity will give relief in either case under certain conditions, but certainly not as a matter of course merely because injury to the fee is threatened. See 5 Pomeroy, Equity JURISPrudence (2d. ed. 1919) § 1906; Gannon v. Peterson, 193 Ill. 372, 62 N. E. 210 (1901). And see Note (1921) 14 A. L. R. 1066-1083.

52 That is to say, mere threatened danger is sufficient to entitle one to a remedy regardless of the degree of probability of his interest taking effect in possession and enjoyment. Cf. Horton v. Upham; Hudson v. Wadsworth; Eichelberger v. Barnetz, all supra note 29. 
a present interest in land. Moreover, the law of personal property gives a remedy to the holder of a future interest which has no counterpart in the land law; he may come into equity under certain circumstances and demand that the holder of the present interest give security.

In the land law, by the rule in Shelley's case, a gift to $A$ for life, remainder to his heirs, operates to give $A$ a fee simple. But a like gift of chattels will have no such effect, for the courts have repeatedly held that the rule in Shelley's case is inapplicable to personal property.:3

Coming now to the more general aspects of the law of estates we may ask: Must a remainder in a chattel take effect in possession at the termination of the preceding estate, however and whenever that may occur? Is there any rule that a contingent remainder in a chattel is destructible by merger or forfeiture of the preceding estate while an executory limitation is not? Is the doctrine of merger applicable to personalty at all? Is there a rule that a grantor of a life estate followed by a contingent remainder retains a reversionary interest until the contingency vests? To most of these questions we may answer that so far as American decisions are concerned, we cannot tell. One case seems to have held that a contingent remainder could fail by the determination of the preceding estate, ${ }^{54}$ and another, a slave case, assumed that the holder of the present interest could terminate a contingent remainder by a tortious sale. ${ }^{55}$ Both conclusions seem unsound. The doctrine of destructibility is a result of the rule that the seisin must pass immediately on the termination of a present estate. Seisin has no relation to the modern law of chattels. If, as has been held, $: 0$ the doctrine of destructibility has no relation to equitable interest in land, it would seem it should have no relation to interests in the nature of contingent remainders in personalty. Clearly the doctrine of

53 While it is sometimes held that the rule in Shelley's case is applicable to personalty by way of analogy or as a mere rule of construction, strictly speaking the rule is not applicable to personalty. To that effect are: Belleville Savings Bank v. Anelshaensel, 298 Ill. 292, 131 N. E. 682 (1921); Glover v. Condell, 163 Ill. 566, 45 N. E. 173,35 L. R. A. 360 (1896); Jones v. Rees, 6 Pennew. 504, 69 Atl. 785 (Del. 1908); Hall v. Gradwohl, 113 MId. 293, 77 Atl. 480 (1910); Sands v. Old Colony Trust Co., 195 MIass. 575,81 N. E. 300 (1907); Evans v. Weatherhead, 24 R. I. 502, 53 Atl. 866 (1902). For further citation of cases see: Notes (1905) 4 L. R. A. (N. S.) 471 ; (1910) 29 L. R. A. (N. S.) 1146; (1909) 12 ANN. C.sS. 839; (1908) 8 Col. L. REv. 573; (1909) 23 HARv. L. Rev. 51; (1909) 4 ILL. L. REv. 639.

54 Cole v. Cole, 292 Ill. 154, 126 N. E. 752 (1920), 38 A. L. R. 719 (1925).

55 Price v. Price, 5 Ala. 578 (1843). But see Pickett v. Doe, 74 Ala. 122, 129 (1883); and cf. Jones Ex'rs v. Hoskins, 18 Ala. 489 (1850).

se $\mathrm{C} f$. Astley v. Mickelthwait, 15 Ch. D. 59 (1880); Abbiss v. Burney, 17 Ch. D. 211 (1881). 
forfeiture, which involved a wrong to the lord of the manor, should have no application to chattels. ${ }^{57}$ As to the doctrine of. merger, dicta may occasionally be found to the effect that it applies to chattels. ${ }^{58}$ Such an observation is quite harmless, if all that is meant is that where $A$ has a life interest and also a succeeding remainder those are treated as one interest. ${ }^{50}$ But the conclusion seems unwarranted that a "merger" of chattel interests could destroy contingent interests, though in the one case already referred to that appears to have been held.

While space does not permit us to consider the difficult question of acceleration of future interests, it may be suggested that in general a future interest in personalty is accelerated on failure of a succeeding interest on the theory of construing a testator's intent, and not because this particular type of interest must be accelerated as a matter of law. It is believed that a careful analysis of the cases would disclose a difference between legal interests in land and in chattels in this particular.

Suppose $A$ gives a chattel to $B$ for life, and, if $B$ marries $C$, then to the children of $B$ and $C$. Does $A$ have a reversionary interest before $B$ marries $C$ ? Suppose $A$ purports to assign such an interest to $X$ during the life of $B$, and then $B$ never marries $C$. Does $X$ get the chattel on $B$ 's death? Again the cases give us no conclusive answer. ${ }^{80}$ Professor Gray insisted that there was no doctrine that the "fee" could not be in abeyance in respect to chattels, and he would therefore have said that $X$ got nothing. ${ }^{\text {ex }}$

A much more significant point of comparison is this. Suppose the holder of a life interest in a chattel should sell it for value to one who had no notice of the future interest. Would the purchaser take as against the holder of the future interest? That is : has the holder of a life interest in a chattel the power to destroy future interests by a sale to a bona fide purchaser? Obviously if he has, the future interest is very unlike the analogous

$5 \pi$ But in some of the slave cases American courts have applied the doctrine of forfeiture. A leading case is Broome v. King, $10 \mathrm{Ala.} 819$ (1846). See cases cited supra note 55. In Price จ. Price's Adm'r, 23 Ala. 609, 612 (1853), however, Chilton, C. J., in a concurring opinion, said: "The rule that a particular estate is required to support a contingent remainder is founded upon feudal reasons, which have no application to personal property, and no such estate is necessary to support such remainder in chattels."

58 In re Washburn's Estate, 11 Cal. App. 735, 746, 106 Pac. 415, 420 (1910): "The merger here claimed is of interests in personal property, and if the doctrine of merger may apply in such a case, which is certainly unusual, the same principles would apply as in cases of real estate, we should thinls."

59 Cf. In re Bloodgood, 184 App. Div. 798, 172 N. Y. Supp. 509 (3d Dept. 1918), which was such a case.

${ }^{60}$ But cf. King v. Mitchell, 8 Pet. 326 (U. S. 1834).

${ }^{61}$ GRAY, op. cit. supra note 1 , at $604, n .1$. 
interests in land. Yet if such a result were possible in the present state of the decisions, much could be said in favor of it. Suppose $A$ has a life interest in a Rolls-Royce car. Would it not work a great hardship on a bona fide purchaser from $A$ to discover, after some time, that the car had been devised to $A$ for life only, that $A$ had died and that the car belonged to the remainderman, $B$ ? Aside from such protection as may be afforded under filing or registration statutes, the purchaser has no way of finding out the state of $A$ 's title. True, any purchaser of a chattel is bound at his peril to ascertain the state of his vendor's title, if he would acquire one himself. But our situation is essentially different from that where one purchases from a thief. $A$ is rightfully in possession; moreover, he is not a mere temporary possessor; his possession is for the term of his life. The circumstances all point to him as owner. Hence, it would seem fair that a bona fide purchaser from him should acquire good title.

Will the present state of the authorities permit such a result? As has already been suggested, Professor Gray discussed substantially this proposition when he inquired whether the life tenant could be regarded as a sort of trustee for himself and the remainderman. ${ }^{62}$ His conclusion, as was also that of Professor Holdsworth, ${ }^{63}$ was to the effect that the authorities do not sustain this view. However, it is believed that the historical materials do not preclude the view suggested. Indeed, no less an authority than Fearne seems to have favored this theory, ${ }^{c s}$ as does also the author of the eighteenth edition of Williams on Personal Property. ${ }^{65}$

The historical argument against the view that the holder of the present interest has the power to pass an absolute title to a purchaser for value is based to a large extent on the case of Hoare v. Parker," which Professor Gray admits furnishes "a dangerous ground for argument." "7 According to the report of that case it involved an action of trover for plate by one who claimed under a remainderman against a party to whom it was pawned for value by a tenant for life. At the time the action was brought, the life tenant was dead. The pledgee had no notice of the remainderman's interest. The plaintiff was permitted to recover. The case does not disclose what the settlement was except that the plate was given to trustees for the use of the life tenant durante viduitate. But it would seem that the life

62 Ibid. 70.

637 HoLDSWORTH, loc. cit. supra note 3.

c4 Fearne, Contingent Remainders (10th ed. 1844) 401, 413.

e5 Williams, Personal Property (18th ed. 1926) 48.

662 T. R. 376 (1788).

e7 GraY, op. cit. supra note 1 , at 70. 
tenant had only an equitable interest as a beneficiary and therefore the case is hardly a precedent for a case where there was no trust, the life holder having a legal interest. Indeed, the report is too obscure to amount to much as a precedent..$^{6 s}$

Moreover, the English case of In re Swan ${ }^{60}$ clearly indicates that the truśt theory was still regarded as possible in 1915 when that case was decided. The facts were that a testatrix had bequeathed certain jewelry to her daughter for life with a remainder to her son. On the daughter's death some of the articles were found to have been broken up and others were missing. The son brought an action for compensation out of the daughter's estate. This was resisted on the ground that, the action being based solely on tort, it died with the person. The court allowed compensation on the theory that the action was not one of tort, but rather for the breach of duty of a trustee or fiduciary. Sargent, J., in the opinion of the court, said:

“... I see no reason why the first taker should not be deemed as to the possession of the articles to be a trustee for the remainderman subject to her own life interest, and to be subject in that respect to the ordinary law of trust; or, if that is not a correct way of putting it, it may well be that the first taker is in the position of a bailee of the article the possession of which on her death she is through her legal personal representative bound to deliver over to the ultimate taker." 70

Among the American decisions, aside from the slave cases, none have been found where an action has arisen between a remainderman and a bona fide purchaser from the holder of a life interest in a chattel. At least three slave cases involve the rights of a bona fide purchaser. In one of them the holder of an executory limitation recovered in trover against the bona fide purchaser from the holder of the present interest; ${ }^{71}$ in another a remainderman came into equity and compelled a bona fide purchaser from the life holder to give security for the safe keeping of the chattel pending the determination of the life interest; ${ }^{72}$ and in the third case remaindermen were given relief in a bill in equity against a bona fide purchaser from the life holder. ${ }^{73}$ It is doubtful if there are any other cases presenting this situation. Another slave case involves an action by the

${ }^{68}$ And see the suggestion in 7 HoLDSwORTh, loc. cit. supra note 3 , that the trust theory was perhaps forwarded by one or two seventeenth century cases.

${ }^{69}$ [1915] 1 Ch. 829.

70 Ibid. 835.

71 Rogers v. Randall, 2 Spear 38 (S. C. 1843).

i2 Lyde v. Taylor, 17 Ala. 270 (1850). But cf. Chisholm v. Starke, 3 Call 25 (Va. 1801).

${ }^{73}$ Jones v. Zollicoffer, N. C. Term R. 212 (1817). 
remainderman to recover on a contract made by the life tenant on the theory that the plaintiff was the beneficiary of a trust. The court refused to allow a recovery on this theory.:

In view of what has already been said about the significance of the slave cases as precedents, it would seem that these three decisions would hardly be enough to lead us to conclude that a remainderman's interest in a chattel is indestructible by the holder of the life interest.

There is, however, another line of cases, nearly all of which involve slaves. In these cases, the remainderman sues, ordinarily after the death of the holder for life, but before the remainderman has acquired possession, the form of the action being trover, detinue, replevin, or some other action at law. These decisions recognize that he can recover in these actions in a court of law. ${ }^{75}$ Thus it may be argued, since these are actions at law, the remainderman has a legal, not an equitable interest, which must be indestructible. In the first place, in answer to such a contention, it should be said that, when the slave cases are eliminated, only a few are left. In the second place, even if we recognize these cases as authority for the proposition that an action by the remainderman in a court of law will lie, it does not follow that the future interest is indestructible by a sale by the life owner to a bona fide purchaser. It should be noted that we do not have to say that the life holder is a trustee, thus implying all the legal consequences of that category in the law, nor do we need to say that the remainder-

\footnotetext{
i4 See Bogle v. N. C. R. R., supra note 36, at 420: "The position that a tenant for life is a trustee or quasi trustee for the remainderman is not tenable." The action was assumpsit. Cf. Russell v. Kearney, 27 Ga. 90 (1859) ; Lafferty's Ex'r. v. Murray, 27 Tex. 372 (1S64); see Burnett v. Roberts, 15 N. C. 81,82 (1833).

is Woodley v. Findlay, 9 Ala. 716 (1816) (detinue for a slave); Price v. Price, supra note 55 (detinue for slaves); Thrasher v. Ingram, $32 \mathrm{Ala}$. 645 (1858) (detinue for slaves); Taber v. Packwood, 2 Day 52 (Conn. 1805) (action on the case); Griggs v. Dodge, 2 Day 28 (Conn. 180j) (account); Lott v. Mreacham, 4 Fla. 144 (1851) (replevin for slares); Booth v. Terrell, 16 Ga. 20 (1854) (trover for slaves); Phillips v. Crews, 65 Ga. 274 (1880) (apparently action for money had and received); Sharman v. Jackson, 30 Ga. 224 (1860) (trover for slaves); Keen v. Macey, 3 Bibb. 39 (Ky. 1813) (judgment for purchaser from life tenant in action of detinue for slaves, reversed); Adie v. Cornwell, 3 T. B. Mion. 276 (Ky. 1326) (detinue for slaves); $M^{\prime}$ Call v. Lewis, 1 Strob. 442 (S. C. 1847) (trover for slaves); Nix v. Ray, 5 Rich. 423 (S. C. 1852) (trover for slave); Bradley v. Mosby, supra note 36 (detinue for slaves).

Similar cases may be found with respect to an action by the holder of an executory limitation in a chattel. Rogers v. Randall, supra note 71 (trover for slaves); Clarkson v. Booth, supra note 36 (detinue for slave); Dashiell v. Dashiell, 2 Har. \& G. 127 (MId. 1828) (detinue for slaves); Royall v. Eppes, 2 IIunf. 479 (Va. 1811) (detinue for slaves); cf. Bartlett v. Patton, 33 W. Va. 71, 10 S. E. 21 (1889) (assumpsit by a reversioner).
} 
man has an equitable interest. All we need to conclude is that the life holder has a power to extinguish the remainder by alienating to a bona fide purchaser, and the remainderman is under a liability to have his interest extinguished under those circumstances. The complete "bundle" of legal relations implied in the terms "trust" and "equitable interest" need not be dragged into the discussion. If it be asked : under what concept of the common law do you explain this rule if not under the trust theory?--it might be answered that the law should not be permitted to fail for want of a category. But in fact, if analogies are necessary, one need not seek far to find them. A conditional vendor of a chattel under modern statutes, the owner of a bearer negotiable instrument, of a bill of lading ińdorsed in blank, or of a share of corporate stock indorsed in blank under the Uniform Stock Transfer Act, is under a liability to have his ownership cut off in the hands of a bona fide purchaser. Yet we do not call his interest an equity.

But if the equitable or trust theory is still insisted upon as an explanation of the power of the life holder to defeat future interests, nevertheless the recognition of the remainderman's privilege of bringing these actions in a court of law may not be fatal to the theory. The beneficiary of a trust may sometimes bring an action at law in the protection of his equitable interest. ${ }^{76}$ What we are concerned with here is not remedies but a theory of substantive legal relations.

While there seems to be no case holding that a bona fide purchaser in the situation under discussion may win in an action against him by the remainderman, there are a few American decisions in which a trust theory is clearly adhered to. It must be conceded, however, that on analysis these cases prove little. Abbott v. Wagner, ${ }^{77}$ a recent Nebraska case, is typical. The facts involved a life estate coupled with a limited power of disposal, and a remainder. A bill in equity was brought by the remainderman in the life of the life holder to charge the transferee of the latter as a constructive trustee for the benefit of the remainderman. Relief was granted on this theory, the court observing:

"But if we are to recognize that the remainderman, in such a case, has any interest in the property which courts of equity will protect from waste, fraud, profligacy, and wilful and reckless extravagance on the part of the life tenant; after coming into possession, then certainly the court not only has the power, but is under a solemn duty, to do all things necessary to afford

76 See BOGERT, TruSTS (1st ed. 1921) 467, 468.

i7 108 Neb. 359, 188 N. W. 113 (1922). 
such protection either by requiring adequate security or appointing a new trustee." 78

Similar dicta are found in two slave cases where the question of requiring security of the life tenant or an accounting in equity was up for discussion. In Horry v. Glover, Chancellor Harper said :

"It is hardly necessary to say, that at common law, there could be no limitation of personal chattels to one for life, with remainder to another, and that a gift for a day or an hour, vested the whole in the first taker. Executory devises and the limitations of the trusts of personalty, by which alone such dispositions can be rendered effectual, are exclusively the creatures of Equity." 70

And in Smith v. Daniel the court said:

"A tenant for life is considered in the nature of a trustee for those in remainder, and the court may, therefore, take all the necessary steps to prevent or restrain an abuse of his trust."

Similar dicta are to be found in other decisions. ${ }^{82}$ The difficulty with cases of this sort is that they are merely deciding that the life holder is under a fiduciary duty to the remainderman to preserve the property. But the argument we have already made with respect to the use of actions at law cuts both ways. Because the life holder is under a fiduciary duty, it does not follow that we should put him in the category of trustee and thus give him a power to pass an absolute title to a bona fide purchaser. Because a life tenant of land is liable in an equitable action for waste by the remainderman it does not follow that the life tenant is a trustee.

From the American authorities it is evident that we can draw no conclusions about the point under consideration. A few slave cases will not justify us in holding that the life holder cannot destroy the remainder. On the other hand we have no direct authority to the effect that he can destroy it.

Is it not possible, however, to discern some rather definite tendencies in the law, from which we may predict the action of the courts? Certainly the trend today is in favor of greater alienability of chattels. Uniform bills of lading acts, uniform stock transfer acts, uniform warehouse receipts acts, and uni-

${ }^{78}$ Ibîd. 380, 188 N. W. at 121.

i9 2 Hill Eq. 515, 522 (S. C. 1837).

$802 \mathrm{MrcCord}$ Eq. 143, 149 (S. C. 1827).

81 Damon v. Dickson, 7 Hawaii 699 (1889); Welsch v. Belleville Savings Bank, 94 Ill. 191 (1879); Glover v. Condell, supra note 53; Homer v. Shelton, supra note 38; Leggett v. Stevens, 185 N. Y. 70, 77 N. E. 874 (1906); Rastetter v. Hoenninger, 214 N. Y. 66, 103 N. E. 210 (1915). 
form conditional sales acts all show the tendency to protect the purchaser of a chattel.

Much more definite evidence of the tendency to protect the purchaser from the holder of the present interest is found in a group of statutes requiring the recording of instruments creating certain types of future interests in chattels. While these statutes vary considerably, the Alabama statute will illustrate the type. Section 6893 of the Alabama Code of 1928 is as follows:

"All loans in writing, wills, or conveyances creating estates in personal property, on condition, in reversion, or remainder, or in which the use is separated from the right, other than the conveyances hereinbefore in this article specified, and under which possession is suffered to remain for three years with the party entitled to the estate or use, vest an absolute estate in the person so having possession for such number of years, as to creditors and purchasers of such person, unless such loan, will, or conveyance is recorded within such time in the county where such property is." 82

Similar statutes are found in Arkansas, ${ }^{83}$ Florida, ${ }^{84}$ Illinois, ${ }^{85}$ Kansas, ${ }^{\text {si }}$ Kentucky, ${ }^{87}$ Missouri, ${ }^{88}$ Mississippi, ${ }^{80}$ Ohio, ${ }^{90}$ Tennessee, ${ }^{91}$ Texas, ${ }^{92}$ Virginia, ${ }^{93}$ and West Virginia. ${ }^{94}$ Of course, these statutes are not recent. The Virginia statute, for example, was enacted in substantially its present form in 1785.05 Moreover, the force and effect of a few of the statutes may be weakened by a somewhat obscure provision apparently excluding its application to ". . . any estate or interest . . . which shall be upon valuable consideration and bona fide and lawfully conveyed." 00 Yet they do show appreciation of a necessity which arose as soon as life interests and other long term interests in chattels were common. It may be said that these statutes do not purport to declare the common law, and that they may indicate that prior to their enactment the common law was otherwise. In reply it

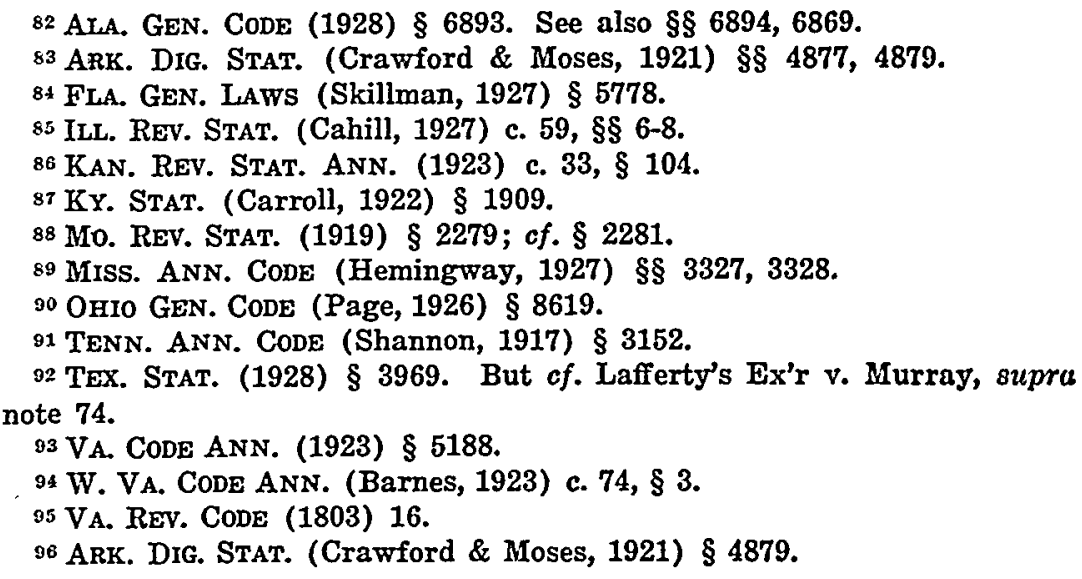


may be answered: whatever the legislators may have thought, the common law was not settled on the subject about which they were legislating, nor indeed can it be regarded as settled today. But these statutes may give us some indication as to the lines along which it ought to be settled.

One rather serious objection to the position contended for, however, has not yet been mentioned. Whatever we may say about future interests following life interests in chattels, the authorities are clear that, in the absence of statutes, a bailee cannot cut off the interest of a bailor by a sale to a bona fide purchaser, nor can a conditional vendee cut off the interest of a conditional vendor in this manner..$^{07}$ In the case of conditional sales this situation has been remedied to a considerable extent by statutes, but it must be conceded that the statutes changed the common law. However, is it not possible to distinguish between a future interest after a term in a chattel and a future interest after a life interest? The former (ordinarily termed a bailment) is, as a practical matter, generally temporary, of short duration. True, the law does not require this. A bailment may be for a hundred years if the parties desire. But experience shows that people, as a rule, do not make such bailments. On the other hand, the interest of the life holder is of more permanent character, and accordingly more likely to mislead the innocent purchaser. While the evidence of a bailment may be readily obtainable because recent, the facts of the creation of a life interest may have arisen so long before as to have passed out of the minds of all but the life owner himself.

Hence, this proposition may be suggested. It is open to the courts to hold as follows: If chattels are given to $A$ for life, or are given to $A$, his executors, administrutors, and assigns, followed by a gift over on some contingency, A has the pouer to destroy the future interest by a sale to a bona fide purchaser. It is not asserted that this is the law, but that it is in accordance with present tendencies, and that the existing precedents do not preclude such a decision.

Why, it may be asked, are there no recent cases directly in point? The answer would seem to be: because people do not as a rule create such future interests without the intervention of a trust. If a trust intervened, on well known principles, the future interest would be destroyed on a transfer by the trustee to a bona fide purchaser. The proposition contended for amounts to little more than this: the courts should do what the creator of the interest would himself have done if he had been a careful draughtsman and had conformed to modern practices.

97 WILlistoN, SALES (2d ed. 1924) $\S \S 423,325$. Cases on rights of a bailor to recover a chattel from a bona fide purchaser from a bailee are collected in 6 C. J. 1147, n. 25. 
So far we have considered questions on which the modern authorities are few or entirely lacking. Aside from a few points on the matter of future privileges of enjoyment, the law of future interests in chattels personal and in land can neither be said to be in agreement nor in direct conflict; the authorities to a large extent simply do not make common ground. An examination of the modern cases on future interests in personalty disclose that most of the cases concern three subjects: the distribution of corporate dividends, income, and other similar rights and privileges between life tenant and remainderman; the duty of the life tenant to give security on suit of the owner of the future interest; and the question of whether the future interest is vested or contingent. The first two are utterly unrelated to the law of estates and future interests in land. The third, which really includes a number of distinct classes of problems, comes close enough to the feudal law of estates in a few particulars to make comparison worth while. To deal adequately with the law of vested and contingent future interests in personalty would require a separate article. Nothing of the sort is attempted here. But in so far as that law may throw light on the applicability of the land law, we should make some reference to it. I

In the land law, the term "vested" seems to have referred originally to investiture with a portion of the seisin.98 Obviously any holder of a present freehold interest came within the designation "vested," as did also a remainderman, if there was no condition precedent to his interest taking effect in possession other than the termination of the preceding estates of freehold. A reversion was also regarded as vested. Long before seisin ceased to be a vital concept in land law the reversioner and remainderman ceased to be thought of primarily with reference to the seisin, but the distinction between vested and contingent interests survived. Today, the terms vested and contingent are constantly applied to future interests in personalty as well as realty. But to get at the real problem involved in cases using these terms, we must ask: what difference in legal consequences will it make whether the interest is vested or contingent? Sometimes the problem is merely the question: is there a condition precedent to the interest taking effect or not? Often a particular form of this question is: can we imply a condition precedent that the holder of the interest must survive the period of distribution? This question originally arose only in connection with personalty, and indeed has been said to involve a different meaning of the term vested from that used in the

9s HaWkins, Wills (2d ed. 1912) 265. But $c f$. Kales, Future INTERESTs (2d ed. 1920) § 30 . 
land law; ${ }^{99}$ but it is clear, today, that the same inquiry is made as to interests in land, ${ }^{100}$ though it may be that the implication of such a condition precedent is less strong in the land law. Again, the distinction between vested and contingent future interests may raise the question of validity under the rule against perpetuities. It may raise the question of the rate of taxation under a taxation statute drawing a distinction between vested and contingent interests. It may raișe a question of the acceleration of a future interest on the failure of the preceding one. Sometimes, the question whether an interest is vested or contingent involves an inquiry into its alienability, although today in most jurisdictions some kinds of contingent interests both in land and in personalty are alienable. In the land law it might, if remainders were involved, raise a question of destructibility. But as we have seen, the doctrine of destructibility of contingent remainders by merger or forfeiture would seem to be inapplicable to personalty. The terms "vested" and "contingent," then, are significant today primarily as designations of one or more of the legal consequences herein described.

What operative facts give rise to vested or contingent future interests? Obviously, no single answer can be given to this question. The decisions are almost innumerable on the question of what words are construed as conditions precedent and what as conditions subsequent. But that has little to do with the theory of estates. The important doctrine derived from the land law is that a future interest is vested if there is no condition precedent to its taking effect in possession other than the termination of the preceding vested estates of freehold. Does this doctrine apply to future interests in personalty? Or are all future interests in personalty contingent because there is a condition precedent to their taking effect in possession, to-wit: the termination of preceding present interests? In answering this question, we must look askance at those cases where the issue was: must the legatee survive the period of distribution. For the courts often say the interest is vested, when they merely mean that there is no implied condition precedent that the legatee survive the period of distribution, or as some have said, that the future interest is transmissible. Without doubt, if

${ }^{99}$ GRAY, op. cit. supra note $1, \S 118$; KaLES, op. cit. supro note $98, \S 495$.

100 Examples of testamentary dispositions of a mixed residue of realty and personalty where the question was whether the legatee or devisee must survive the period of distribution are found in Bland $\mathrm{v}$. Davisson, $77 \mathrm{WW}$. Va. 557, 88 S. E. 1021 (1916); Petition of Norris, 46 R. I. 57, 125 Atl. 34 (1924); Thompson r. Adams, 205 Ill. 552, 69 N. E. 1 (1903).

See also, as to the applicability of the "divide and pay over" rule to realty as well as personalty, Gluck, The "Divide and Pay Over" Rule in New York (1924) 24 CoL. L. REv. 8. 
the precedent interest were a bailment for a term or at will, the bailor's interest would be regarded as vested, for the reason that the court would look at the bailor's interest as a present one. But if the precedent interest is for life, then we have a test as to the applicability of the doctrine from the law of estates. In England the courts have wavered. Evans $v$. Walker, ${ }^{101}$ a case involving the applicability of the rule against perpetuities, held that a future interest in a chattel following a life estate could be vested. To the same effect is Samuda's Trust, ${ }^{102}$ but in that case, though the court assumed that a future interest in chattels following a life interest could be vested for purposes of the rule against perpetuities, in fact the interest in question was held to be contingent. In the case of In re Backhouse, ${ }^{103}$ however, the opposite view was taken. Two cases which involved the question of vesting for purposes of the applicability of a bill of sale registration act took the view that a future interest following a life interest in a chattel is necessarily contingent. ${ }^{104}$

In the United States, such authority as there is accords with Evans v. Walker: ${ }^{105}$ If we add to these decisions the large number of American cases in which it is assumed that a future interest following a life interest in a chattel could be vested, ${ }^{10 n}$ we may fairly conclude that to this extent the doctrine of the land law as to vested future interests has been taken over into the realm of personalty. That is to say, a future interest in a chattel will as a rule be regarded as vested if there is no other condition precedent to its taking effect in possession or enjoyment than the termination of one or more vested life interests. This rule would seem to apply whether the interests be legal or equitable.

Suppose land is devised "to $A$ in fee twenty years after my death." The usual explanation of such a testamentary disposition is that $A$ has an executory limitation which does not vest

\footnotetext{
${ }^{101} 3$ Ch. D. 211 (1876).

102 [1924] 1 Ch. 61 .

103 [1921] 2 Ch. 51.

104 In re Tritton, 61 L. T. 301 (1889); In re Thynne, [1911] 1 Ch. 282.

10 Supra note 101 . Seaver v. Fitzgerald, 141 Mass. 401, 6 N. E. 73 (1886); McAllister v. Elliot, 83 N. H. 225, 140 Atl. 708 (1928); In re Gageby's Estate, 293 Pa. 109, 141 Atl. 842 (1928); cf. Salisbury v. Salisbury, 92 Kan. 644, 141 Pac. 173 (1914).

${ }^{103}$ In the following cases and doubtless in many others this assumption is made: Nicol v. Morton, 332 Ill. 538, 164 N. E. 5 (1928); In re Washburn's Estate, supra note 58; Boal v. Metropolitan Art Museum, supra note 41; Voorhees v. Singer, 73 N. J. Eq. 532, 68 Atl. 217 (1907); Bank of Statesboro v. Futch, 164 Ga. 181, 138 S. E. 60 (1927); Min Young v. Min Young, supra note 36.
} 
until twenty years after the testator's death. ${ }^{16 \cdot 7}$ If, however, a bequest of personalty were made "to $A$ twenty years after my death," it is quite possible that a court would hold it vested on the death of the testator. This would certainly seem to be true if the language were "to $A$ to be paid twenty years after my death." 108 To be sure, the cases in support of this proposition generally raise merely the question whether the legatee must survive the period of distribution, but such a limitation has been held to be vested for purposes of the rule against perpetuities. ${ }^{1 / 3}$

The reason for this distinction between realty and personalty, if such there be, is presumably due to doctrines about seisin which have no application to chattels.

Before concluding, attention should be called to the fact that in a number of states are found statutes making certain rules of real property law applicable to personalty. The New York statute, is as follows:

"The absolute ornership of personal property shall not be suspended by any limitation or condition, for a longer period than during the continuance and until the termination of not more than two lives in being at the date of the instrument containing such limitation or condition; or, if such instrument be a last will and testament, for not more than two lives in being at the death of the testator. In other respects limitations of future or contingent interests in personal property, are subject to the rules prescribed in relation to future estates in real property." 110

It is to be noted that this last clause does not say all rules in relation to future interests in realty are applicable. Indeed, the New York courts have recognized that they are not always applicable, though in many cases this statute has been cited to justify the application to personalty of a rule respecting the land law. While an analysis of these cases is not attempted in this connection, it may be doubted whether the existence of the statutes in question materially modify the conclusions reached herein. Other states are more cautious in respect to statutes on future interests in personalty and the applicability of the land law. The Montana Code provides:

${ }^{107}$ See Butler's note to FEARNE, op. cit. supra note 64, at 1, note a; GruX, op. cit. supra note 1, §§ 793-797; Freund, Three Suggestions Conccrning Future Interests (1920) 33 HARv. L. REv. 526, 536.

108 See 3 WARNER, ADMINISTRATION (3d ed. 1923) § 430.

109 Nicol v. Morton, 332 Ill. 533, 164 N. E. 5 (1928); O'Hare v. Johnston, 273 Ill. 458, 113 N. E. 127 (1916) ; Shepard v. Union \& New Haven Trust Co., 106 Conn. 627, 138 Atl. 809 (1927).

110 N. Y. Personal Property Laty (1917) c. 45, § 11. For a similax statute, see WIS. STAT. (1927) § 230.14.

i11 See the discussion in Chaplin, Susfension of the Power of AlienaTION (3d ed. 1928) $§ \S 458-462$. 
"The names and classification of interests in real property have only such application to interests in personal property as is in this division of the code expressly provided." ${ }^{112}$

The Codes of North and South Dakota and California contain substantially the same provision.113 Clearly, these statutes do not make the law of estates in land applicable to future interests in personalty. !

In Georgia a statute provides that "any estate may be created in the latter [personalty] that can be created in the former [realty]...." 114 This hardly means more than that the same extent of privilege of enjoyment may be created in personalty as in realty. As estates tail are abolished by statute in Georgia, ${ }^{115}$ it would seem that this piece of legislation goes no farther than judicial decision has gone in this respect.

By way of conclusion, the following observations are believed to be substantiated by the discussion which has preceded: We cannot infer that, because a rule is applicable to future interests in land, it applies to future interests in personalty; sometimes the courts have applied these rules, sometimes they have not; more often there are no cases in which the application has been attempted. In any event, the question should not be one of taking over a feudal concept, but of deciding a concrete problem; we should not ask, is it an executory limitation, a remainder or a reversion, but, is it void under the rule against perpetuities, or should the donor rather than the donee take on the termination of the present interest? It would be most unfortunate if the law of personalty were saddled with the incubus of the all but obsolete feudal land law; and it is believed that the courts have not required this, and will not do so. It is also believed that the American courts in most states are open to decide that a future interest following a gift for life or to one, his executors, administrators, and assigns, can be extinguished by a transfer by the holder of the present interest to a bona fide purchaser. On the other hand, though we should avoid taking over the feudal law of estates, we may well treat land and personalty alike in many situations; but whether we do or not, should be a question of policy. Lastly, to argue that there are or are not estates and future interests in personalty is meaningless. We know that there may be privileges of enjoyment with a life quantum, and future privileges of enjoyment to take effect after a life interest; we also know that the legal consequences incident

112 MONT. REv. CoDES (Choate, 1921) § 6698. See also $§ 6718$.

${ }^{113}$ N. D. Comp. Laws ANN. (1913) § 5280; S. D. Rev. Code (1919)

§ 287; CAL. Crv. CODE (Deering, 1923) § 702.

114 GA. ANN. CODE (Michie, 1926) § 3656.

115 Ibid. § 3661. 
to these interests are not the same as the legal consequences incident to analogous privileges of enjoyment in land. When a new question arises in the law of future interests in chattels it should be decided on its merits, and not on the basis of the feudal concepts. 